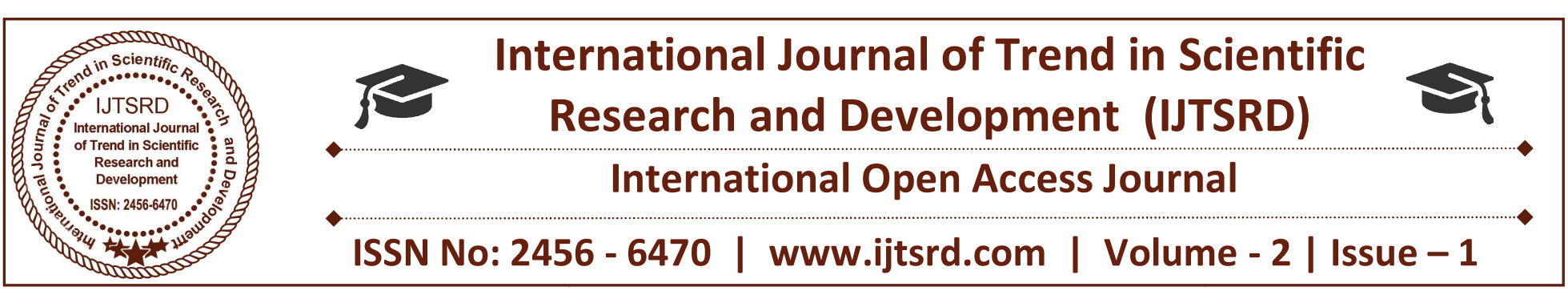

\title{
Study of Influencing Attributes in the Context of Purchasing Behaviour in the Retail Stores with Special Reference to Pune City
}

\author{
Rahul Wagh \\ MBA, (Marketing), Pune, India, Faculty: SKN \\ Sinhgad School of Business Management, Pune
}

\author{
Dr. Anil Dongre \\ MBA, UGC-NET-Ph.D, Head UG Department of \\ Management, North Maharashtra University, Jalgaon
}

\begin{abstract}
A study was conducted to observe the impact of impulse purchase factor on shoppers' Purchase Volume in the Punecity Departmental stores. This study explored the situational impulse purchase factors namely, Store environment, Store distance, Store density and Store shopping duration. The model was tested with data collected from a consumer survey carried out in the Pune departmental stores. Further, it was studied using the statistical tool SPSS. The outcome of the study was that more the purchaser spent in the store (shopping duration) the more is the impulse purchase volume. This model may help the retail managers to understand better the situational factors of impulse purchasers and to increase sales volume.
\end{abstract}

Keyword: Departmental store, Impulse purchase, shopping duration, store distance, store solidity.

\section{INTRODUCTION}

The retailing sector in India has undergone a significant revolution during the last two decades. Today's retail 'store' is constructed around customers, not commodities. The true experience of consumption begins in the marketplace for most consumers, and today's consumers face a broad range of choices in that marketplace for how they use their resources, time, and the retail outlets available to them. Consumer purchasing decisions are frequently made at the point of purchase and may be heavily influenced by what takes place there. A great many factors contribute to purchase decision especially impulse purchase, including consumer characteristics, and situational factors. By identifying those factors, retailers may improve store layout and design, merchandising, atmosphere and staffing decisions ominously. Those issues are a critical basis for developing competitive advantage in today's dynamic and competitive grocery market.

\section{Literature Review}

Time and companionship were shown to be critical factors in purchasing behaviour of Hispanic customers in a US mall setting (Nicholls, Roslow and Dublish, 1997). The impact of situational factors on consumer purchasing behaviour has been studied in the past research widely. There are studies that explored the impact of particular types of situational influences, including store atmospherics, music, colours, scent, store crowding, and merchandising. Bolton et al (2016) investigated the importance of store location and suggests that Department stores (e.g., limited assortment stores) may also be located at more convenient locations or locations, which enable multipurpose shopping.

Bell et al (2010) analysed the impact of retail price format on store choice, had identified three key metrics: (1) number of shoppers, (2) number of trips (Frequency of visits), and (3) average spending per trip (Purchase volume). Further insists that, pricing is central to retail decision-making: "Nothing is more important in business than getting the pricing strategy right". Baker et al (2010) on store massing suggests that massing can trigger both perception of physical density and a negative emotional reaction to physical density (which leads to consumer dissatisfaction. Perceived density is a 
subjective estimate of the number of people in a space. It is an antecedent of perceived retail crowding and purchasing outcomes (Eroglu, Machleit and Barr, 2005). Crowding could restrict or interfere with individuals' goals and might influence a shopper not to visit the crowded aisle and not to go for impulse purchase.

$\mathrm{H}$ 1: Lower store mass is more likely to produce higher level of impulse purchase than higher masscircumstances.

Time spent shopping is an important factor in determining how much the shopper will buy. The longer the shopper remains in a store, the more he or she will buy (Underhill, 1999). Nicholls, Roslow and Dublish(1997) found that slow shoppers (who spent more than an hour in the mall) purchased more items and spent more money than quick shoppers
H 2: Distant shoppers are more likely to spend more money and purchase more items than near shoppers.

Time dimension is important in sales situations and might alter shopping behaviour. Shortage of time may reduce both planned and unplanned purchases (Senthilnathan, 2014). Travel time may influence purchasing. Past research suggests that there is a positive association between travel time to store and purchasing outcome, in such a way that distant shoppers (who travelled for half an hour or more to mall) are more likely to purchase and spend more money than near shoppers who travelled for less than half an hour to store

H 3: Slow shoppers are more likely to spend more money and purchase more items than quick shoppers.

\section{Model of the Situation Factors}

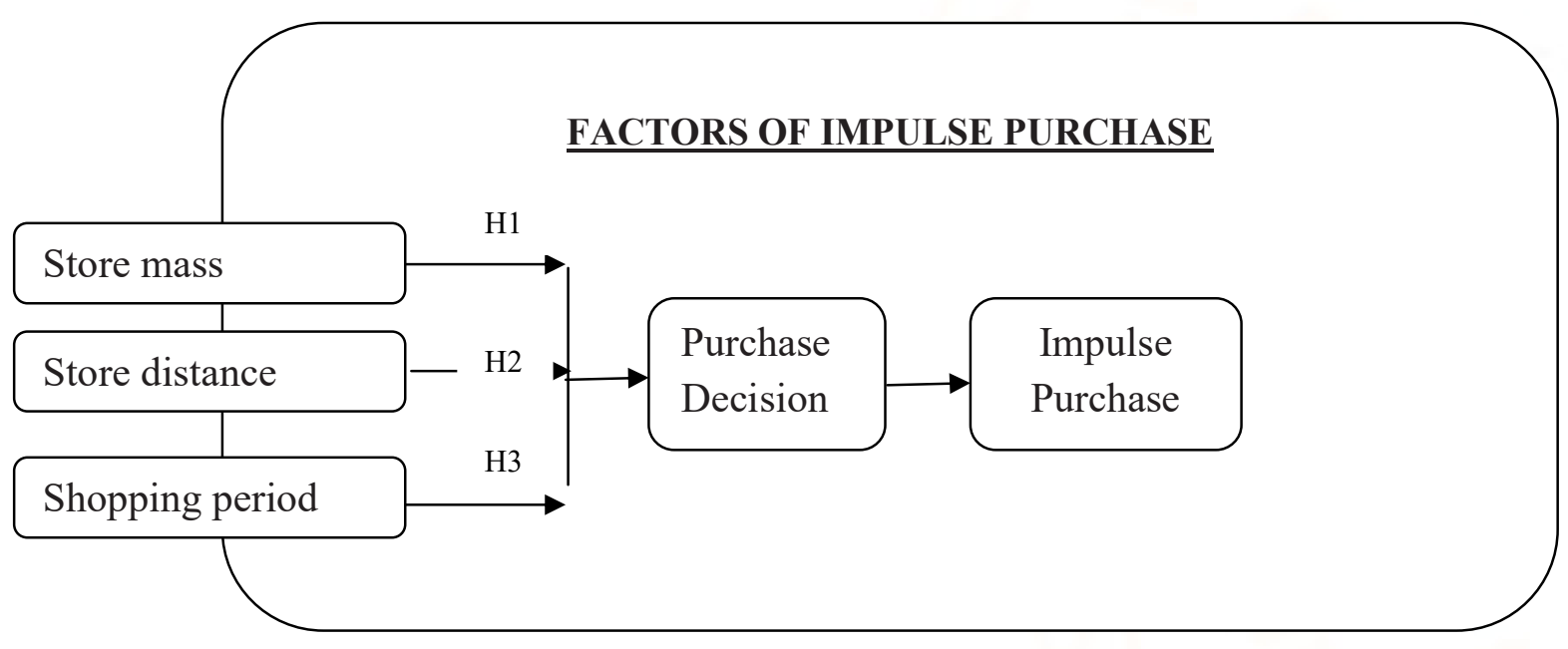

\section{Methodology}

Data for this study was obtained from the consumer survey. The survey was carried out in the department stores in Pune city. After the respondents had been done with shopping, they were asked to fill-in the questionnaire. A sample of 621 shoppers was finally obtained. Summary statistics on consumer sample is presented in table 1.

Table 1 - Summary Statistics on Sampled Respondents, N =621

\begin{tabular}{|l|l|}
\hline STATISTICAL SUMMARY & Value \\
\hline Female & 53.3 \\
\hline Average age of the respondent (years) & 21 to 30 \\
\hline $\begin{array}{l}\text { Average Annual family Income } \\
\text { (in lakhs, in Rs) }\end{array}$ & 3 to 6 \\
\hline Average Expenditures for major shopping trips & $751-1500$ \\
\hline Average total time spent inside the store & 30 to 45 \\
\hline Average distance of the store (in KM) & 1 to 2 \\
\hline
\end{tabular}

Source: Primary Data 
International Journal of Trend in Scientific Research and Development (IJTSRD) ISSN: 2456-6470

It is observed that $53.3 \%$ were female respondents and $46.7 \%$ were male respondents were considered for the study. It shows that female respondents were predominant. Most of the respondents $(74.6 \%)$ were in the age groups 21 to 30 and 31 to 40 .

Out of 621 respondents $57 \%$ of the respondents' shopping time spent in each of the shopping trip is on an average 30 to 45 minutes. 274 respondents (44\%) are travelling on an average 1 to $2 \mathrm{Km}$ to purchase store items.

Data was analysed using different statistical techniques, including descriptive statistics, cross tabulation analysis and Chi-Square analysis. Multivariate Regression analysis was conducted to understand better the contribution of the situational factors towards the Purchase Volume of the respondents.

Table 2 - Relationship between the respondents' Impulse Purchase and Store Density

\begin{tabular}{|c|c|c|c|c|c|c|c|c|}
\hline \multicolumn{2}{|c|}{ Impulse Purchase Volume (in INR) } & $\begin{array}{l}\frac{\hat{n}}{2} \\
\frac{8}{2} \\
\frac{2}{b}\end{array}$ & $\frac{8}{\frac{8}{1}}$ & 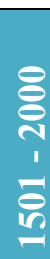 & $\begin{array}{l}\text { है } \\
\text { ले } \\
1 \\
\overline{8} \\
\text { ปิ }\end{array}$ & $\begin{array}{l}8 \\
8 \\
8 \\
0 \\
8 \\
8 \\
8\end{array}$ & 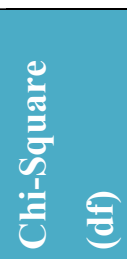 & 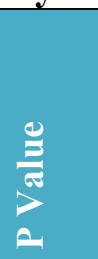 \\
\hline \multirow{5}{*}{ 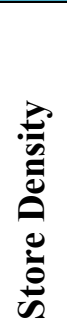 } & Highly Disagree & 0 & 3 & 6 & 0 & 1 & \multirow{5}{*}{$\begin{array}{l}88.41 \\
(12)\end{array}$} & \multirow[t]{5}{*}{$.000^{*}$} \\
\hline & Disagree & 19 & 25 & 32 & 7 & 3 & & \\
\hline & Neither agree / nor disagree & 42 & 26 & 22 & 1 & 1 & & \\
\hline & Agree & 49 & 63 & 66 & 12 & 9 & & \\
\hline & Highly Agree & 65 & 112 & 63 & 0 & 0 & & \\
\hline
\end{tabular}

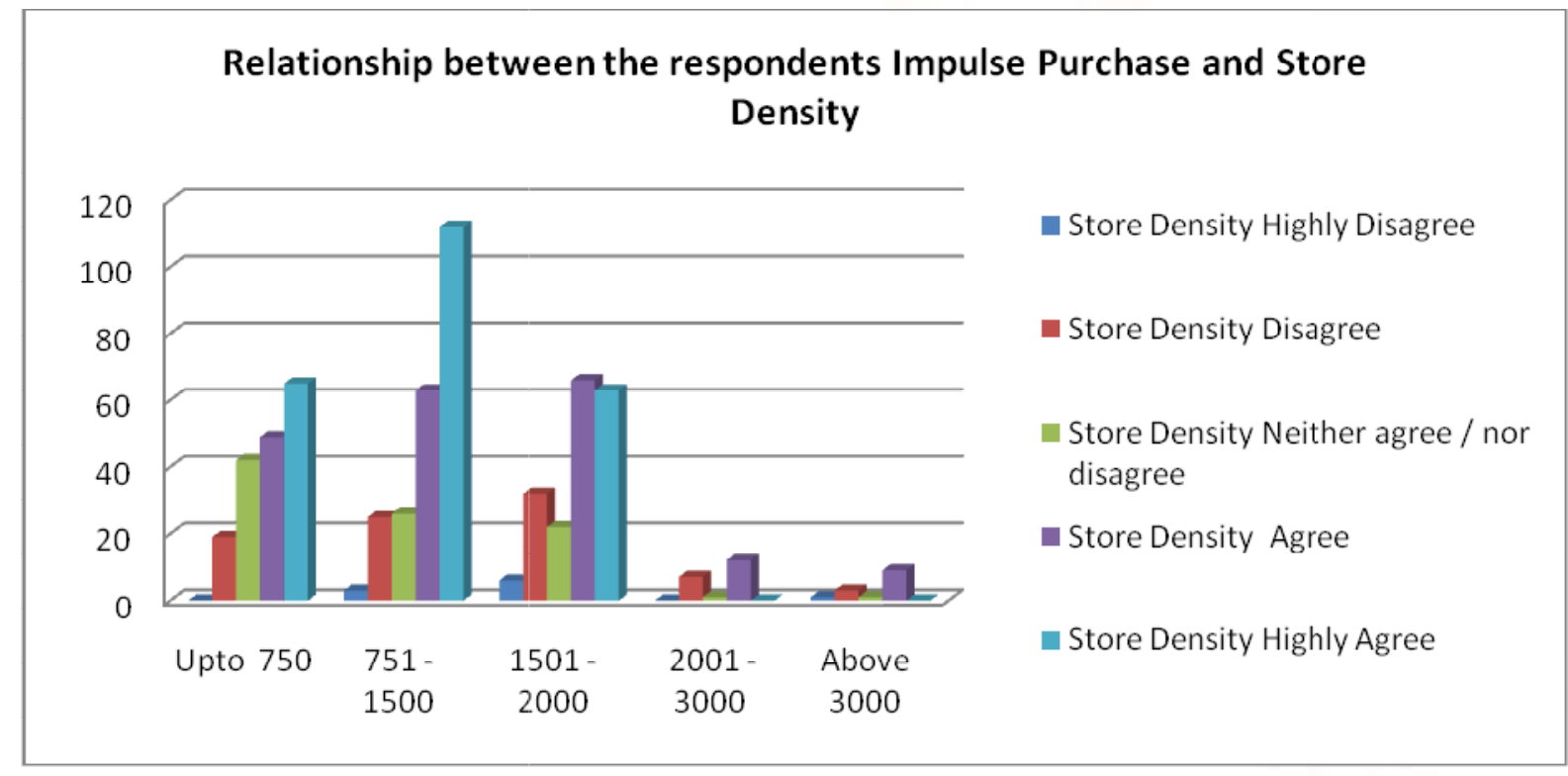

Note: * denotes significance at $1 \%$ level

Source: Primary Data

It is observed from the table 2 that with $\chi^{2}(12, \mathrm{~N}=621)=88.41, \mathrm{p}<0.01$, there is a significant relationship between respondents' Impulse Purchase Volume and Store density among Pune city. The Chi-square value of 88.41 shows that the null hypothesis (H0) is rejected at $1 \%$ level of significance. Respondents feel that store density has an adverse effect on impulse purchase. 
International Journal of Trend in Scientific Research and Development (IJTSRD) ISSN: 2456-6470

Table 3 - Relationship between the respondents' Impulse Purchase Volume and Store Distance

\begin{tabular}{|c|c|c|c|c|c|c|c|c|}
\hline \multicolumn{2}{|c|}{$\begin{array}{l}\text { Impulse Purchase Volume (in } \\
\text { INR) }\end{array}$} & 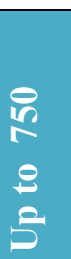 & $\frac{8}{\frac{8}{1}}$ & $\begin{array}{l}8 \overline{8} \\
\text { तิ } \\
1 \\
\overline{8} \\
\frac{1}{n}\end{array}$ & $\begin{array}{l}\text { हి } \\
\text { ల్ } \\
1 \\
\overline{8}\end{array}$ & $\begin{array}{l}8 \\
\text { हे } \\
\text { ले } \\
8 \\
8 \\
8 \\
\end{array}$ & 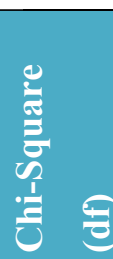 & 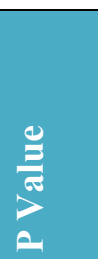 \\
\hline \multirow{5}{*}{ 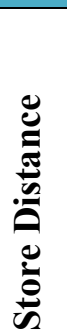 } & Highly Agree & 70 & 5 & 128 & 0 & 10 & \multirow{5}{*}{$\begin{array}{l}2.85 \\
(16)\end{array}$} & \multirow[t]{5}{*}{$.000^{*}$} \\
\hline & Agree & 45 & 142 & 82 & 0 & 5 & & \\
\hline & Neither agree/ nor Disagree & 13 & 56 & 13 & 11 & 1 & & \\
\hline & Disagree & 0 & 37 & 1 & 0 & 1 & & \\
\hline & Highly Disagree & 0 & 0 & 1 & 0 & 0 & & \\
\hline
\end{tabular}

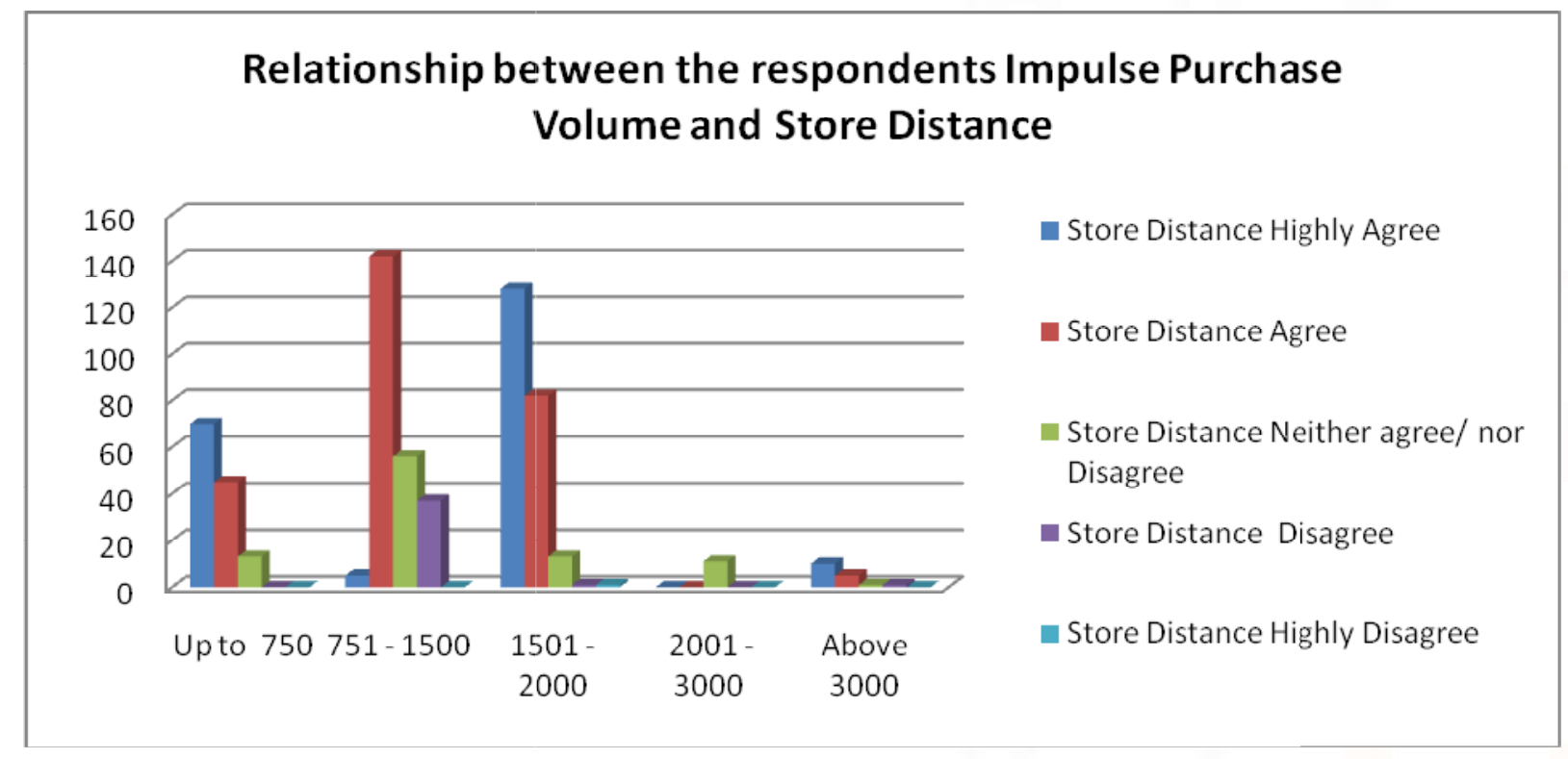

Note: $*$ denotes significance at $1 \%$ level, $* *$ denotes significance at $5 \%$ level Source: Primary Data

It is observed from the table 3 that with $\chi^{2}(16, \mathrm{~N}=621)=2.85, \mathrm{p}<0.01$, there is a significant relationship between respondents' Impulse Purchase Volume and Store Distance in Pune city. The Chi-square value of 2.85 shows that the null hypothesis $\left(\mathrm{H}_{0}\right)$ is rejected at $1 \%$ level of significance. Store distance does not deter the respondents towards impulse purchase. 
International Journal of Trend in Scientific Research and Development (IJTSRD) ISSN: 2456-6470

Table 4 - Relationship between the respondents' Purchase Volume and Shopping Duration

\begin{tabular}{|c|c|c|c|c|c|c|c|c|}
\hline \multicolumn{2}{|c|}{ Impulse Purchase Volume (in INR) } & 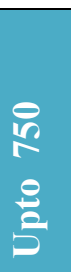 & $\begin{array}{l}\frac{8}{8} \\
\frac{1}{1} \\
\frac{1}{n}\end{array}$ & 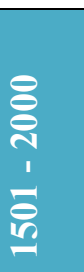 & 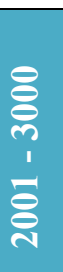 & $\begin{array}{l}\text { 8े } \\
\text { हे } \\
8 \\
8 \\
8 \\
\end{array}$ & 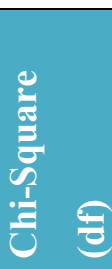 & $\begin{array}{l}\frac{8}{\mathrm{E}} \\
\stackrel{\mathrm{e}}{\mathrm{e}}\end{array}$ \\
\hline \multirow{5}{*}{ 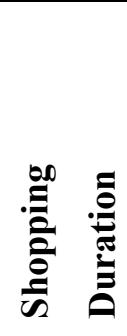 } & Highly Agree & 2 & 5 & 11 & 0 & 0 & \multirow{5}{*}{$\begin{array}{l}15.44 \\
(12)\end{array}$} & \multirow[t]{5}{*}{.000} \\
\hline & Agree & 80 & 116 & 150 & 0 & 2 & & \\
\hline & Neither agree / nor Disagree & 35 & 82 & 35 & 11 & 5 & & \\
\hline & Disagree & 14 & 37 & 26 & 0 & 10 & & \\
\hline & Highly Disagree & 0 & 0 & 0 & 0 & 0 & & \\
\hline
\end{tabular}

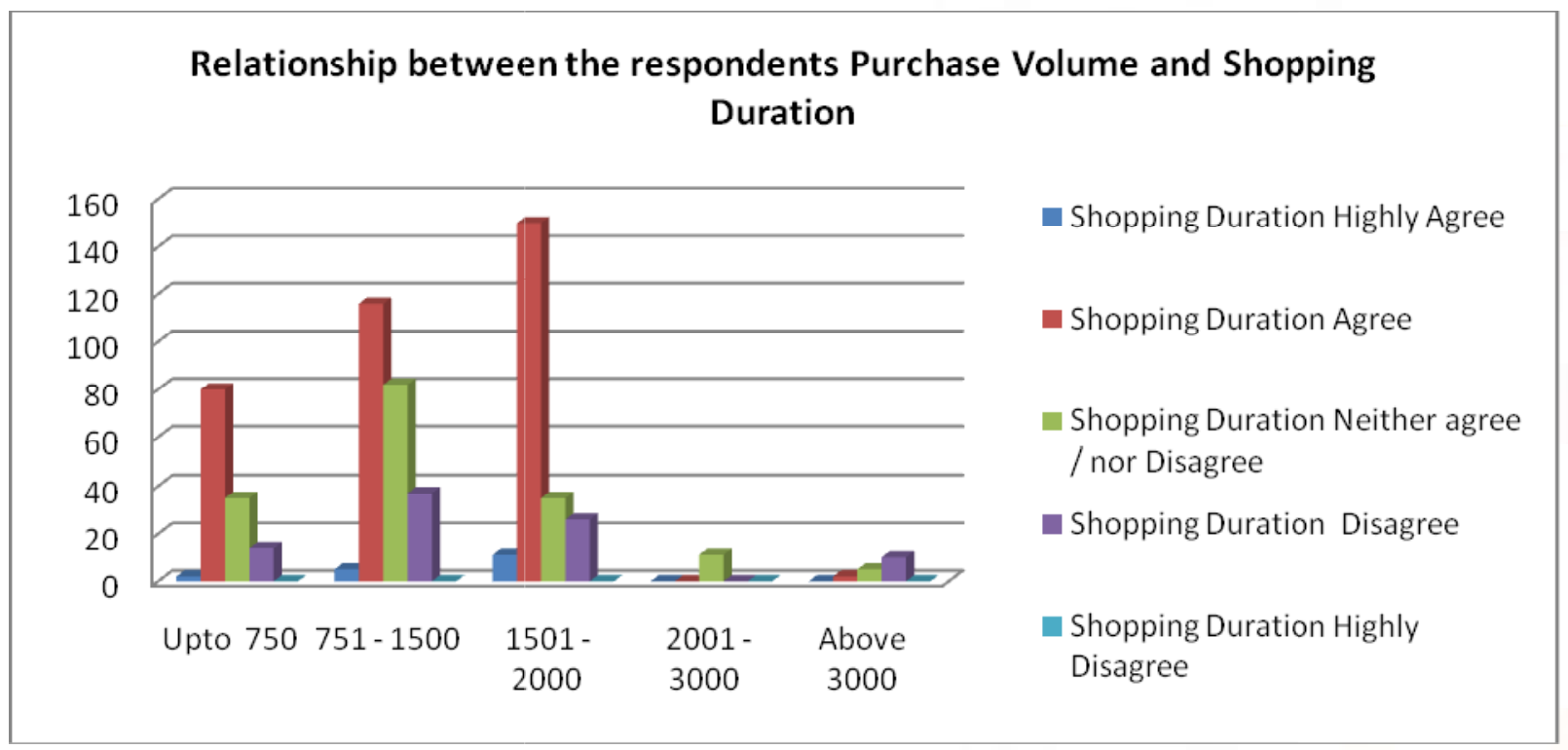

Note: $*$ denotes significance at $1 \%$ level, ** denotes significance at $5 \%$ level Source: Primary Data

It is observed from the table 4 that with $\chi^{2}(12, \mathrm{~N}=621)=15.44, \mathrm{p}<0.01$, there is a significant relationship between respondents' Impulse Purchase Volume and Shopping Duration among Pune city. The Chi-square value of 15.44 shows that the null hypothesis $\left(\mathrm{H}_{0}\right)$ is rejected at $1 \%$ level of significance. Result implies that the duration of shopping has a positive impact on impulse purchase. 
Table 5 Regression Analysis for the model

\begin{tabular}{|c|c|c|c|c|c|}
\hline $\begin{array}{l}\text { Predictor variables with } \\
\text { ImpulsePurchase volume } \\
\text { as the DV }\end{array}$ & $\mathbf{R}^{2}$ & $\begin{array}{l}\text { Standardized } \\
\text { coefficient Beta }\end{array}$ & F - Value & $\mathrm{t}$-value & Sig \\
\hline Store distance & \multirow[t]{3}{*}{0.505} & .104 & \multirow{3}{*}{$\begin{array}{l}25.134 \\
\mathrm{p}=0.000 *\end{array}$} & -8.662 & .000 \\
\hline Store density & & -.105 & & -2.999 & .003 \\
\hline Shopping duration & & .307 & & .194 & .846 \\
\hline
\end{tabular}

Note: * denotes significance at $1 \%$ level, $* *$ denotes significance at $5 \%$ level

Source: Primary Data

To study the model, a regression analysis - enter method was used. The dependable variable is the Impulse Purchase Volume and the independent variables are Store distance, Store density and shopping duration. The regression model's ANOVA $F$ value is 25.134 and it is significant at $1 \%$ level. The regression model's coefficient of determination $\left(\mathrm{R}^{2}\right)$ is .505 , which is a moderate coefficient for the model.

$\mathrm{IPV}=.104$ (Store distance) -.105 (Store density) +.307 (Shopping duration)

\section{Conclusion}

One of the main sources of income for the department store is the impulse purchase. To understand the factors which influence the impulse purchase in department stores was initiated. Data was analysed using descriptive statistics, including one-way analysis of variance. Research results indicate that high perceived density and large-scale shopping were factors that significantly contribute to higher level of impulse purchasing outcomes. Also, store distance is not a deterrent for the impulse purchase. By using this model, retailers may better predict the consumer response to impulse purchase factors, and thus can design a store strategy that will encourage particular pattern of shoppers' behaviour.

\section{References}

1) Baker Juie, A. Parasuraman, Dhruv Grewal \& Glenn B. Voss, (2002) 'The influence of multiple store environment cues on perceived merchandise value and patronage, Journal of Marketing, pp.120141.

2) Bell, D. R, Ho, T and Tang,( 2001), 'Store Choice and Shopping Behaviour: How Price format works', California Management Review, 43(2),pp 56-74.
3) Bolton Ruth N, P. K. Kannan and Matthew D. Bramlett, (2000),'Implications of Loyalty Program Membership and Service Experiences for Customer Retention and Value', Journal of the Academy of Marketing Science. Volume 28,No. 1, pp 95-108.

4) Donovan, R. J. and J.R. Rossiter, (1982). "Store Atmosphere: An Environmental Psychology Approach", Journal of Retailing, (58), 1, 34-58.

5) Donovan, R. J., Rossiter, J.R., Marcoolyn, G. and A. Nesdale (1994), "Store Atmosphere and Purchasing Behavior", Journal of Retailing, (70), 3, 283-294.

6) Eroglu, S. A.; Machleit, K., and T.F. Barr, (2005). "Perceived retail crowding and shopping satisfaction: the role of shopping values", Journal of Business Research, (58), 8, 1146-1153.

7) Nicholls, J. A. F., Roslow, S., S. Dublish (1997). „Time and companionship: key factors in Hispanic shopping behavior", Journal of Consumer Marketing, 14 (2/3), 194-205.

8) Solgaard .S. Hans and Torben Hansen ,(2003), 'A hierarchical Bayes model of choice between supermarket formats', Journal of Retailing and Consumer Services 10, pp.169-180.

9) Underhill, P. (1999). Why we buy: the science of shopping.US: Simon and Schuster. 